\title{
Preliminary evaluation of associated viruses in production systems of cape gooseberry, purple passion fruit, and rose
}

\section{Evaluación preliminar de virus asociados a sistemas productivos de uchuva, gulupa y rosa}

JOSEPH CUTLER ${ }^{1,9}$

JULIANE LANGER'

SUSANNE VON BARGEN'

ORLANDO ACOSTA-LOSADA²

FÁNOR CASIERRA-POSADA ${ }^{3}$

ADRIANA CASTAÑEDA-CÁRDENAS

MÓNICA BETANCOURT-VÁSQUEZ

WILMER CUELLAR

EDUARDO ARVYDAS-STASIUKYNAS

DENISE ALTENBACH ${ }^{8}$

CARMEN BÜTTNER'

Fruit deformation and leaf blistering in purple passion fruit (Passiflora edulis Sims).

Photo: J. Cutler

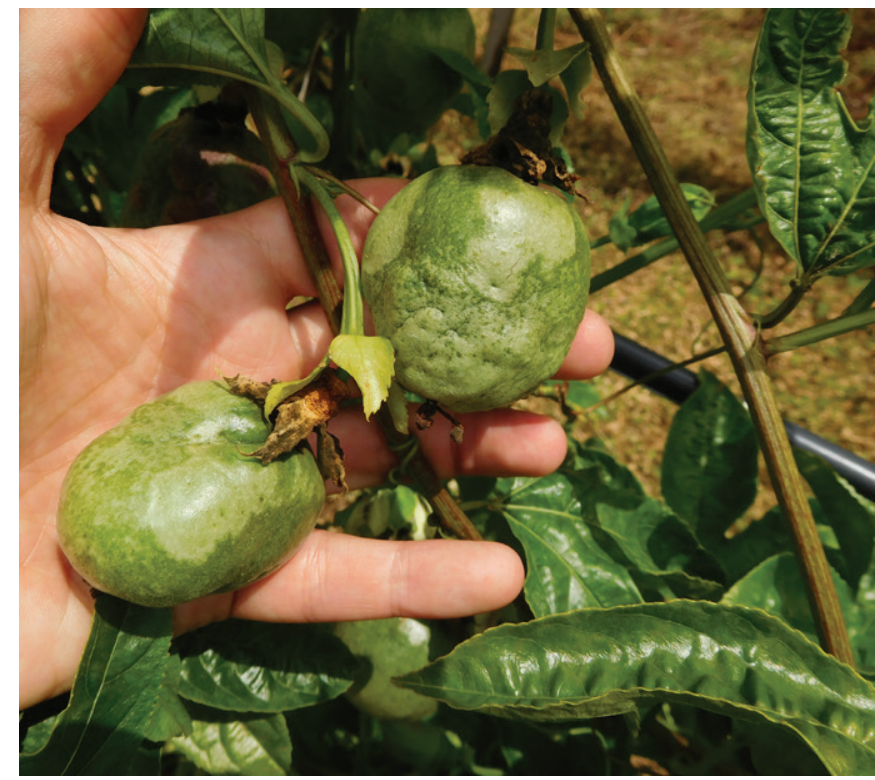

\section{ABSTRACT}

Plant viruses may pose a threat to crops in Colombia. To evaluate the potential risk of yield losses due to plant virus infection, a literature analysis followed by a first field study was carried out focusing on purple passion fruit (Passiflora edulis Sims), cape gooseberry (Physalis peruviana L.), and ornamental rose (Rosa sp.), which are important Colombian exports. Over the past three years, plant material was collected from 21 farms in

\footnotetext{
1 Humboldt-Universität zu Berlin, Albrecht Daniel Thaer-Institut für Agrar- und Gartenbauwissenschaften, Fachgebiet Phytomedizin, Berlin (Germany). ORCID Cutler, J.: 0000-0002-2027-9649; ORCID Langer, J.: 0000-0001-6574-3831; ORCID Bargen, S.v.: 0000-0001-8321-1572; ORCID Büttner, C.: 0000-0002-2086-2594

2 Universidad Nacional de Colombia, Facultad de Medicina, Bogota (Colombia). ORCID Acosta-Lozada, O.: 0000-0002-1267-098X

3 Universidad Pedagógica y Tecnológica de Colombia (UPTC), Facultad de Ciencias Agropecuarias, Tunja (Colombia). ORCID Casierra-Posada, F.: 0000-0001-7508-5174

4 Instituto Colombiano Agropecuario (ICA), Dirección Técnica de Análisis y Diagnóstico Agrícola, Bogota (Colombia) ORCID Castañeda-Cárdenas, A.: 0000-0003-1403-6787

5 Corporación Colombiana de Investigación Agropecuaria (AGROSAVIA), Mosquera (Colombia). ORCID Betancourt-Vásquez. M.: 0000-0002-6702-9524

6 International Center for Tropical Agriculture (CIAT), Cali (Colombia). ORCID Cuellar, W.: 0000-0003-4702-3237

Hacienda Misiones, Mesitas del Colegio (Colombia). ORCID Arvydas-Stasiukynas, E.: 0000-0002-3140-0803

BIOREBA Laboratories, Reinach (Switzerland). ORCID: Altenbach, D.: 0000-0003-2774-2437

9 Corresponding author. joseph.cutler@agrar.hu-berlin.de
} 
Cundinamarca and Boyacá, Colombia, two regions that are in close proximity to El Dorado International Airport, the country's largest air freight terminal. Plants were visually inspected and subsequently tested by bioassay and serological methods. Overall, in the samples investigated by the two diagnostic methods, plant viruses were detected. Detected viruses belong to the genus Poty-, Tobamo-, Nepo-, Ilar-, and Tospovirus. The extent of the distribution and occurrence of these viruses in each crop has to be determined in a representative field study. Such a monitoring program could be supported by a standardized farmer interview. The development of suitable plant virus diagnostic and managements tools is the focus of a cooperation project between German and Colombian universities, the Colombian Agricultural Institute (ICA), the Colombian Corporation of Agricultural Investigation (AGROSAVIA) and the International Center for Tropical Agriculture (CIAT).

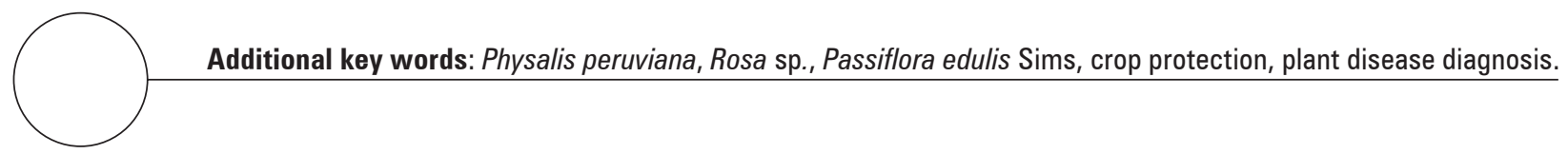

\section{RESUMEN}

Los virus representan una amenaza para las plantas cultivadas en Colombia, y algunos estudios indican que las pérdidas económicas causadas por estos problemas fitosanitarios podrían evitarse mediante procedimientos preventivos estándar. Como objeto de estudio, se seleccionaron tres importantes productos de Colombia, como lo son: rosa ornamental (Rosa sp.), uchuva (Physalis peruviana L.) y gulupa (Passiflora edulis Sims). En el presente artículo, se muestran los primeros desarrollos resultantes del monitoreo de virus en estas plantas, para determinar el estado de las virosis en fincas colombianas. Se realizaron análisis serológicos de 21 fincas en Cundinamarca y Boyacá, Colombia, en 2016-18. El objetivo de esta investigación fue el desarrollo de un protocolo piloto para el diagnóstico rutinario, que se pueda aplicar en un programa de certificación de material vegetal para la determinación de la presencia de virus, en varios productos hortícolas colombianos. Con base en este protocolo, se pueden determinar los riesgos que representan ciertos virus y se puede considerar la necesidad de certificar el material de siembra evaluado según la presencia de virus. Se están desarrollando herramientas de diagnóstico confiables y prácticas, para la detección de los virus más relevantes, en un proyecto conjunto entre universidades alemanas y colombianas, el Instituto Colombiano de Agropecuario (ICA), la Corporación Colombiana de Investigación Agropecuaria (AGROSAVIA) y el Centro Internacional de Agricultura Tropical (CIAT).

Palabras clave adicionales: Physalis peruviana, Rosa sp., Passiflora edulis Sims, protección de cultivos, diagnóstico de enfermedades de plantas.

Received for publication: 05-03-2017 Accepted for publication: 30-05-2018

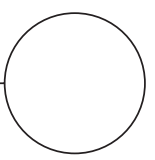

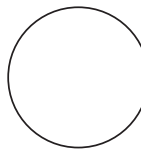

Colombia's agricultural export sector has advanced and in parallel the need for phytosanitary control has become more important. There is knowledge about the presence of pests, fungi, and bacterial diseases, but only little about plant viruses and their potential impact on plant or fruit quality and yield quantity. We focused on cape gooseberry (Physalis peruviana), rose (Rosa sp.), and purple passion fruit (Passiflora edulis Sims), three important plant cultivars for Colombia's export market.

Cape gooseberry, known as uchuva in Colombia, belongs to the family Solanaceae and genus Physalis. Colombia is the largest producer of uchuva followed by South Africa (Mazorra et al., 2006). Uchuva started to have commercial importance in Colombia in 1985 (Chaves, 2006). Colombia is the country with the largest area of cultivation, from 800 to 1,000 ha producing between 15 to $18 \mathrm{t} \mathrm{ha}^{-1}$ (Fischer et al., 2014). The quality of domestic and exportable postharvest uchuva is largely correlated with proper plant pathogen management. Cape gooseberry is affected by pests and several fungal, bacterial and viral pathogens. Increasing occurrence may be due to uncontrolled distribution of primary planting material among the farmers. Fungal pathogens such as Fusarium oxysporum, Alternaria spp., Cladosporium spp., Phytophtora infestans, Cercospora spp., and Phoma spp., the bacterial pathogen Ralstonia solanacearum, and plant viruses belonging to the genus Alfamovirus, 
Bigeminivirus, Comovirus, Cucumovirus, Fabavirus, Furovirus, Hybrigeminivirus, Ilarvirus, Luteovirus, Nepovirus, Orthotospovirus, Potexvirus, Potyvirus, Tobamovirus, and Tymovirus have been reported to occur in cape gooseberry (Rodríguez et al., 2016; Aguirre-Ráquira et al., 2014). But only few studies present deeper research into the complete genomic sequence and the complex relationship between genotype and phenotype of such plant viruses. For instance, Gutiérrez et al. (2015) present the complete genome sequence of an isolate of Potato virus X (PVX) infecting cape gooseberry in Colombia.

Purple passion fruit, known as gulupa in Colombia, belongs to the family Passifloraceae and genus Passiflo$\mathrm{ra}$. The main diseases infecting gulupa in Colombia were summarized by Gutiérrez et al. (2015). They include the bacteria Xanthomonas axonopodis and the viruses Soybean mosaic virus (SMV) and Cucumber mosaic virus (CMV). On a global level further viruses have been described: Passion fruit ringspot virus (PFRSV), Passiflora virus Y (PaVY), East Asian passiflora virus (EAPV), Okra mosaic virus (OkMV), Maracuja mosaic virus (MarMV), Passion fruit crinkle virus (PCV), Passion fruit rhabdovirus (PRV), Passiflora latent virus (PLV), Passion fruit mottle virus (PFMoV), Purple granadilla mosaic virus (Gil et al., 2017), and Passion fruit yellow mosaic virus (PFYMV) (Morales et al., 2002).

Ornamental roses are perennial flowering plants of the genus Rosa, in the family Rosaceae. The floral industry is dominated by Holland, which produces $83 \%$ of the world's cut flowers, followed by Colombia, the second largest exporter worldwide (PMA, 2015). The main exported flower from Colombia is the rose which totals 365 million USD, and $70 \%$ of its cut roses are exported to the USA (PMA, 2015). Global studies have reported the following viruses to infect rose: Prunus necrotic ringspot virus (PNRSV) (Fajardo et al., 2015), Apple mosaic virus (ApMV) (Sertkaya, 2010; Abtahi, 2015), Arabis mosaic virus (ArMV) (Abtahi, 2015), Tobacco ringspot virus (TRSV) (McDaniel et al., 1971), Tomato ringspot virus (ToRSV) (Halliwell and Milbrath, 1962), Raspberry ringspot virus (RRSV) (Von Bargen et al., 2015), Rose yellow leaf virus (RYLV) (Mollov et al., 2014), and Rose rosette virus (RRV) (Laney et al., 2011).

To extend the knowledge on both the occurrence of plant viruses in cape gooseberry, purple passion fruit and ornamental roses and their impact on crop yield and quality, we conducted a first field study. Biological and serological laboratory investigations completed the visual inspection of selected fields in the main growing area of these crops.

\section{MATERIAL AND METHODS}

Forty-four fields on 21 farms were inventoried for the incidence of virus-suspected symptoms in cape gooseberry, purple passion fruit, and rose in one of the main exporting Colombian cultivation areas (Fig. 1). Visual inspection is always the first step to identify the cause of plant damage. On the basis of the observed symptoms, laboratory investigations can be initiated to confirm the particular suspicion. We focused on virus-suspected symptoms such as chlorotic discoloration, leaf blistering, necrosis, stunting, and partial decline. Mechanical inoculation of the putative viral pathogen with the diseased tissue on indicator plants was applied to verify the infectivity of the agent. Different enzyme-linked immune assays (ELISA) were used to identify the viral pathogens.

\section{Sampling}

The field survey was carried out from 2016 to 2018 and comprised 21 national and export production sites in the Cundinamarca and Boyaca departments of Colombia (Fig. 1). The distribution of the sites visited were 10 cultivated farms of cape gooseberry, five of purple passion fruit and six of ornamental roses. Initial assessment of the health status of the plants in the field was conducted with a stratified random sampling pattern according to Delp et al. (1986) (Fig. 1). The distribution of the sites visited were 10 cultivated farms of cape gooseberry, five of purple passion fruit and six of ornamental roses. This pattern divides the field into regions of higher and lower disease risk. The disease foci were established by the general managers of each farm. As recommended, samples were collected from disease foci, as well as along other parts of the fields (Mavrodieva, 2004). Percent error is reduced using this sampling design compared to systematic entire field $\mathrm{X}$ and $\mathrm{W}$ shaped patterns or diagonal or partial field sampling patterns (Fletcher, 2006). To represent the impacted area, 10 to 20 samples were taken based on farm size, if procurable. Samples were collected in BIOREBA ${ }^{\circledR}$ extraction bags, transported in cooler bags and stored at $4^{\circ} \mathrm{C}$ before being investigated.

\section{Mechanical inoculation}

Bioassays are used to diagnose a virus by its reactions in a variety of plant species, to test the infectivity of an isolate using local lesion hosts, and to propagate viruses. According to Hull (2009) plant homogenate was rubbed onto the surface of the leaf of the test plant to break the surface cells without causing too 


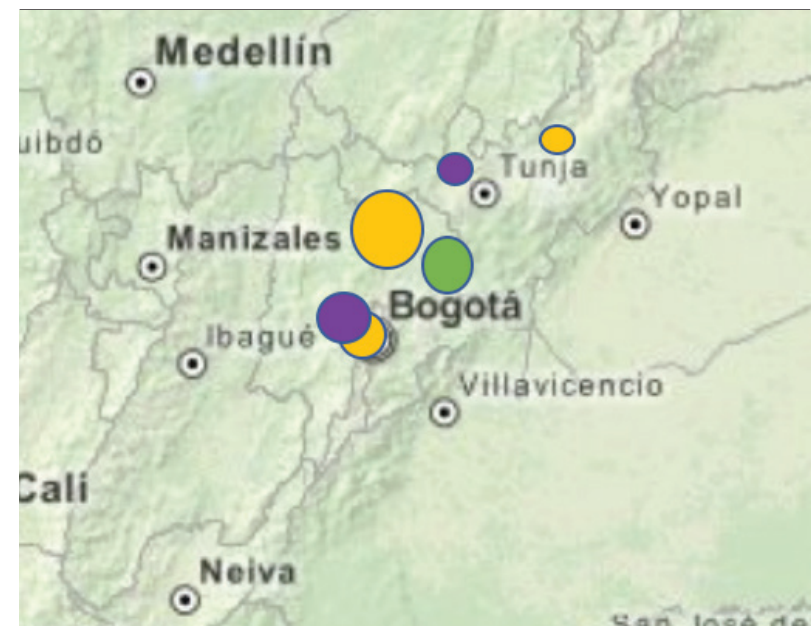

Figure 1. Sampling sites in Cundinamarca and Boyacá, Colombia: cape gooseberry (orange), purple passion fruit (purple), ornamental rose (green).

much mechanical damage. Chenopodium quinoa, Nicotiana benthamiana, Nicotiana clevelandii, Nicotiana tabacum L. cv. Samsun-NN, and Cucumis sativus were used as test plants.

\section{Enzyme-linked immunosorbent assay (ELISA)}

The detection of plant viruses using the ELISA was introduced to plant virology in the late 1970s. This method was selected among the diagnostic techniques due to its affordability, extreme sensitivity, and potential for measurement (Clark and Adams, 1977). ELISA was conducted with leaf material at Humboldt University (Berlin, Germany) and BIOREBA laboratories (Reinach, Switzerland) using available antibodies of previously described known viruses: Cucumber Mosaic Virus (CMV), Potato virus Y (PVY), Tobacco mosaic virus (TMV), and Tomato spotted wilt virus (TSWV) in passion fruit and cape gooseberry, Prunus necrotic ringspot virus (PNRSV), Tobacco streak virus (TSV), Arabis mosaic virus (ArMV), and Tomato ringspot virus (ToRSV) in rose, and Soybean mosaic virus
$(\mathrm{SMV})$ in passion fruit. In addition to these plant virus species specific tests carried out in the Double Antibody sandwich-ELISA format, a Plate-Trapped Antibody (PTA)-ELISA using a Potyvirus-group specific antibody was performed to test plant material of all three cultivars. All tests were carried out according to protocols recommended by the supplier.

\section{RESULTS AND DISCUSSION}

Virus suspected symptoms were observed in all three crops: cape gooseberry, purple passion fruit and ornamental roses (Fig. 2). Plants showed mild to extreme yellowing, browning, stunting, spots, mosaics, curling, blistering, mottling, chlorosis, ringspots, deformation, discoloration, vein clearing, and variegation in leaves, fruits, and flowers. A total of 320 samples of 113 cape gooseberry, 112 purple passion fruit, and 95 ornamental roses were collected and examined for different globally known viruses in the laboratory. After specific viruses were not detectable in our samples [e.g. Potyvirus-group, PVY, TMV, CMV (in all cultivars), ArMV (in rose), and ToRSV, TSWV (in physalis)], testing of these viruses was discontinued. The SMV antibody was only tested for samples collected in 2018, as it was only first developed for passion fruit by BIOREBA at this time. Overall, various viruses have been detected by ELISA so far, yet none of the detected viruses could be transmitted by mechanical inoculation to herbaceous test plants.

All passion fruit farms had plants with symptoms of wilting, yellowing in leaves, distorted, decayed, and/ or misshapen fruit with a similar scattered distribution in high and low areas. In three of the five farms inspected, passion fruit showed unique zebra striped mottling or blistering symptoms of leaves and fruits. Only four out of 112 samples tested were infected with Soybean mosaic virus (Tab. 1). Applying the ELISA this infection was detected first by a genus-specific

Table 1. Detection of particular plant viruses in fruit and leaf samples of diseased cape gooseberry, purple passion fruit and ornamental roses (ArMV: Arabis mosaic virus, PNRSV: Prunus necrotic ringspot virus, PVY: Potato virus Y, TMV: Tobacco mosaic virus, ToRSV: Tomato ringspot virus, TSV: Tomato streak virus, TSWV: Tomato spotted wilt virus, SMV: Soybean mosaic virus). Numbers: virus infected plants/tested plants/collected plants; nt: not tested).

\begin{tabular}{|l|c|c|c|c|c|c|c|c|c|}
\hline \multicolumn{1}{|c|}{ Crop } & ArMV & PNRSV & Potyvirus & PVY & TMV & ToRSV & TSV & TSWV & SMV \\
\hline Purple passion fruit & $\mathrm{nt}$ & $\mathrm{nt}$ & $4 / / 101 / 112$ & $0 / 68 / 112$ & $0 / 68 / 112$ & $\mathrm{nt}$ & $\mathrm{nt}$ & $0 / 33 / 112$ & $4 / / 64 / 112$ \\
\hline Cape gooseberry & $\mathrm{nt}$ & $\mathrm{nt}$ & $11 / / 113 / 113$ & $3 / 113 / 113$ & $0 / 89 / 113$ & $\mathrm{nt}$ & $\mathrm{nt}$ & $0 / 51 / 113$ & $\mathrm{nt}$ \\
\hline Ornamental roses & $0 / 82 / 95$ & $47 / 95 / 95$ & $1 / 59 / 95$ & $\mathrm{nt}$ & $\mathrm{nt}$ & $0 / / 49 / 95$ & $3 / 95 / 95$ & $\mathrm{nt}$ & $\mathrm{nt}$ \\
\hline
\end{tabular}




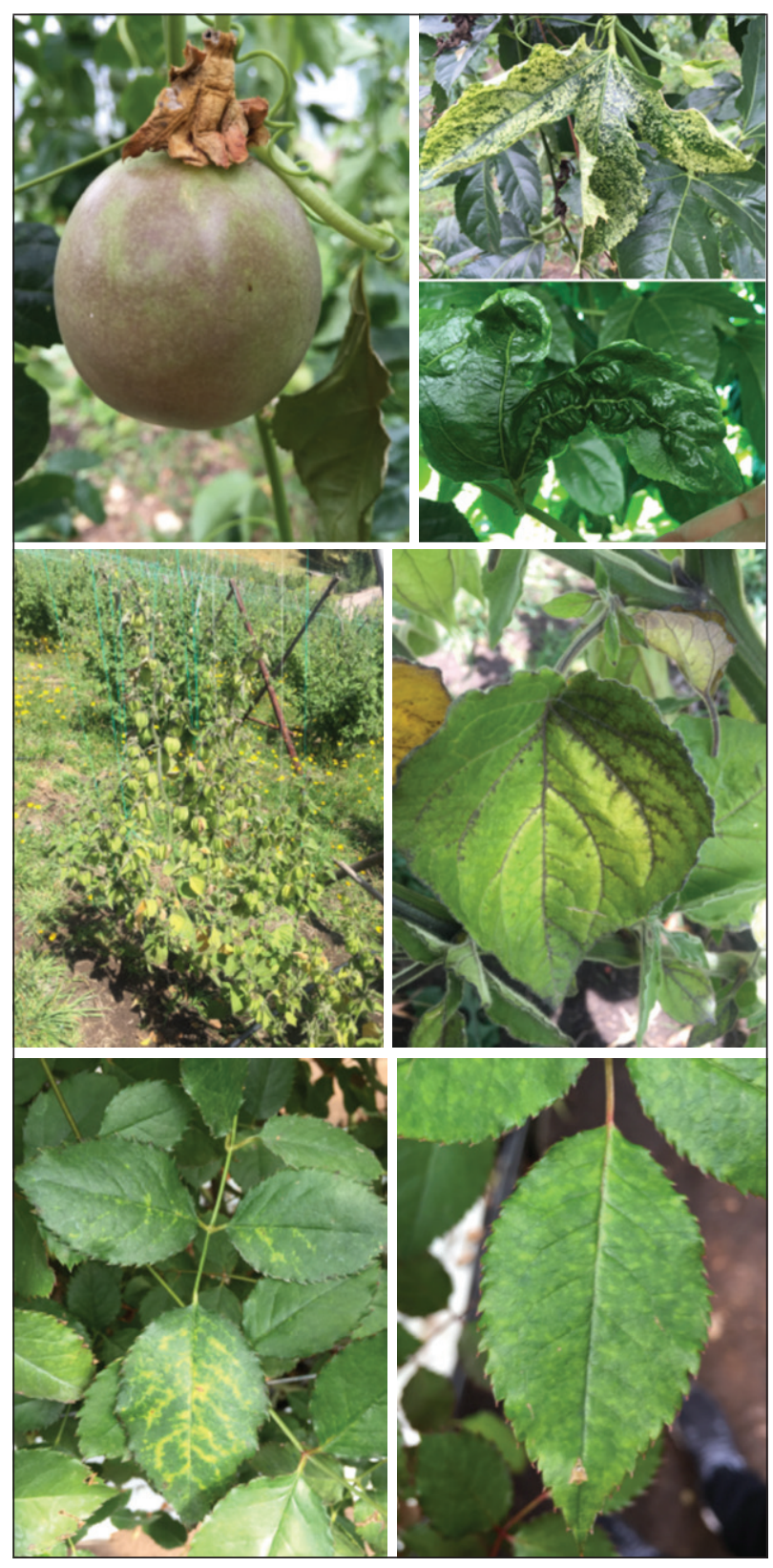

Figure 2. Characteristic symptoms associated with plant virus infection. Row 1: purple passion fruit with discoloration (left), leaf with mosaic (right top) and blistering (right below). Row 2: cape gooseberry with yellow and stunting (left) and vein necrosis (right). Row 3: ornamental rose leaf with oak leaf pattern (left) and mottling (right). antibody and confirmed to be Soybean mosaic virus by using a species specific antibody which was recently developed by BIOREBA to be applied in passion fruit. The four samples, each representing an individual plant, came from two different farms.
Cape gooseberry plants from all farms exhibited similar symptoms of yellowing, leaf spots, mosaic, and distorted fruits. But only 11 out of 113 samples proved to be infected with one of the tested plant viruses (Tab. 1) and originated from seven farms. Those plants are infected with a potyvirus, leaf material of three of them reacted with an antibody against PVY, the type member of the genus potyvirus. Further studies should identify and characterize the Potyvirus infecting cape gooseberry. It might be a distinct strain of PVY, or a potyvirus not kown in cape gooseberry so far or even not at all.

In all of the six rose farms that were involved in the field survey, there was at least one sample containing a plant virus in a scattered distribution in rows. An infection with PNRSV could be detected in about $50 \%$ of tested roses, 3 out of 95 plants tested plants revealed an infection with TSV, one with a Potyvirus (Tab. 1). Most plants that tested positive for PNRSV in ELISA showed a characteristic chlorotic line pattern, named oak leaf pattern. In four farms, all symptomatic leaf samples taken from the variety Freedom were PNRSV-infected independent on the farm they were taken. Samples of the varieties Topaz and Blues were infected with that virus in two of the six farms. This distribution and the fact that no insect vector is known, in spite of extensive surveys suggests that the virus was introduced to the farm with the propagation material, rootstocks or scions.

Significant research on viruses in Colombia has been carried out in recent years. A novel ilarvirus infecting purple passion fruit was detected in Cundinamarca by RT-PCR in the Humboldt University in 2018. Vaca-Vaca et al. (2017) characterized the complete genome sequence of a begomovirus infecting yellow passion fruit (Passiflora edulis) in Valle del Cauca. In Antioquia, Gallo-Garcia et al. (2018) have reported the genome sequence of a noval ilarvirus infecting physalis. It is advisable that further research on the presence of viruses in ornamental roses in Colombia be carried out.

\section{RECOMMENDATIONS AND CONCLUSIONS FROM THIS STUDY}

Our results are a preliminary investigation of the occurrence of plant viruses in Cape gooseberry, purple passion fruit and ornamental roses in Colombia and do not give a reliable countrywide survey in terms of region, climatic conditions, mode of cultivation and 
cultivars. In this first field survey few plant viruses could be detected in the 320 samples. The damage of the plants are therefore either due to other harmful organisms, or caused by previously untested or unknown viruses. A state of the art high-throughput sequencing (NGS) approach should be applied to discover more viruses. With such an approach novel viruses and/or virus complexes can be determined or excluded as the causes of the observed damage.

On the basis of an intensive monitoring and screening at different Colombian production sites the occurrence and impact of particular plant viruses can be determined and economic thresholds can be estimated. With this research, management programs can be recommended.

Such programs would involve training of farmers in recognizing early symptoms of a disease, on-site diagnostic tools to be used by consultants, sanitation measures like disinfection of knives while grafting, and certification of propagation material. Certification of mother seeds, rootstocks and scions to be virus-tested can prevent the transmission and distribution of plant viruses in the field and country, respectively. Farmers propagating their own plants should be aware that even mother plants infected with a virus can infect generative or vegetative relatives. Depending on the virus, this can result in high losses. Training schools and routine diagnostic tools are being developed for a national agricultural certification program that could be established in a common project between German and Colombian universities, the Colombian Agricultural Institute (ICA), the Colombian Corporation of Agricultural Investigation (AGROSAVIA) and the International Center for Tropical Agriculture (CIAT).

An increased attention to the use of virus-free plant material will support Colombian agricultural products domestically and in international export markets (Cutler et al., 2017). A certification of virus-tested plant material can contribute to better quantity and quality in production and contributes to better trade policy decision-making. Many stakeholders in the Colombian supply chain would gain from the knowledge and practical experience in controlling plant pathogens, from small farmers to the major worldwide distributors of Colombia's agricultural and horticultural products.

\section{ACKNOWLEDGMENTS}

Special thanks to Oscar Enrique Fuentes Murillo, Emilio Arévalo Peñaranda and all staff of the Instituto
Colombiano Agropecuario (ICA) involved in the sampling effort, Sergio Lloreda of OCATI for organizing transportation to farms, and the Alcalde Mayor of Bogota Enrique Peñalosa Londoño for his advocacy of plant pathology research in Colombia. Special thanks to Gerhard Fischer of the National University of Colombia for initiating and supporting this project from the beginning. Special thanks to Martina Bandte of Humboldt Universität zu Berlin for her review of the manuscript. Also many thanks to the COST DIVAS Action FA1407 for financial support to participate in meetings and workshops, and for scientific support by members on best practices of NGS technologies in plant virus diagnostics.

Conflict of interests: the manuscript was prepared and reviewed with the participation of the authors, who declare that there exists no conflict of interest that puts the validity of the presented results at risk.

\section{BIBLIOGRAPHIC REFERENCES}

Abtahi, F.S. 2015. Detection and distribution of the important viruses infecting damask rose in floricultures of Isfahan, Markazi, and Kerman Provinces. Modern Gen. J. 10(1), 11-20.

Aguirre-Ráquira, W., D. Borda, and L. Hoyos-Carvajal. 2014. Potyvirus affecting uchuva (Physalis peruviana L.) in Centro Agropecuario Marengo, Colombia. Agric. Sci. 5, 897-905. Doi: 10.4236/as.2014.510097

Chaves, A. 2006. Propagação e avaliação fenológica de Physalis sp. na região de Pelotas-RS. Ph.D. thesis. Universidade Federal de Pelotas, Pelotas-RS, Brazil.

Clark, M.F. and A.N. Adams. 1977. Characteristics of the microplate method of enzyme-linked immunosorbent assay for the detection of plant viruses. J. General Virol. 34(3), 475-483. Doi: 10.1099/0022-1317-34-3-475

Cutler, J., C. Lüchau, J. Langer, S. von Bargen, O.L. Acosta, F. Casierra-Posada, A. Cárdenas, M.B. Vásquez, W. Cuellar, E.A. Stasiukynas, and E. Arévalo-Peñaranda. 2017. Development of a certification program for virus-tested plant material in Colombia: A collaborative initiative. Book of Abstracts. Tropentag 2017, September 20-22, Bonn, Germany.

Delp, B.R., L.J. Stowell, and J.J. Marois. 1986. Evaluation of field sampling techniques for estimation of disease incidence. Phytopathology 76, 1299-1305.

Fajardo, T.V.M., M.B. Nascimento, M. Eiras, O. Nickel, and G. Pio-Ribeiro. 2015. Molecular characterization of Prunus necrotic ringspot virus isolated from rose in Brazil. Ciênc. Rural 45(12), 2197-2200. Doi: $10.1590 / 0103-8478 c r 20141810$ 
Fischer, G., P.J. Almanza-Merchán, and D. Miranda. 2014. Importancia y cultivo de la uchuva (Physalis peruviana L.). Rev. Bras. Frutic. 36(1), 1-15. Doi: 10.1590/0100-2945-441/13

Fletcher, J., C. Bender, B. Budowle, W.T. Cobb, S.E. Gold, C.A. Ishimaru, and R.C. Seem. 2006. Plant pathogen forensics: capabilities, needs, and recommendations. Microbiol. Mol. Biol. Rev. 70(2), 450-471. Doi: 10.1128/MMBR.00022-05

Gallo-García, Y.M., H. Jaramillo-Mesa, L.F. Toro-Fernández, M. Marín-Montoya, and P.A. Gutiérrez. 2018. Characterization of the genome of a novel ilarvirus naturally infecting Cape gooseberry (Physalis peruviana) Arch. Virol. 163, 1713-1716. Doi: 10.1007/ s00705-018-3796-8

Gil, J.G.R., P.J. Tamayo, and J.G. Morales. 2017. Identification and pathogenicity of microorganisms affecting purple passion fruit in Colombia. Rev. Ceres 64(3), 250-257. Doi: 10.1590/0034-737x201764030005

Gutiérrez, P.A., J.F. Alzate, and M.M. Montoya. 2015. Complete genome sequence of an isolate of Potato virus $X$ (PVX) infecting Cape gooseberry (Physalis peruviana) in Colombia. Virus Genes 50(3), 518-522. Doi: 10.1007/s11262-015-1181-1

Halliwell, R. and J. Milbrath. 1962. Isolation and identification of tomato ringspot virus associated with rose plants and rose mosaic virus. Plant Reptr. 46, 555-557.

Hull, R. 2009. Mechanical inoculation of plant viruses. Curr. Protoc. Microbiol. 13, 16B.6.1-6.4.

Laney, A.G., K.E. Keller, R.R Martin, and I.E Tzanetakis, 2011. A discovery 70 years in the making: characterization of the Rose rosette virus. J. General Virol. 92(7), 1727-1732. Doi: 10.1099/vir.0.031146-0

Lüchau, C., J. Cutler, J. Langer, S. von Bargen, and C. Büttner. 2017. Detection and characterisation of a new Ilarvirus in Passiflora edulis. Book of Abstracts, Tropentag 2017, September 20-22, Bonn, Germany.

Mavrodieva, V., L. Levy, and D.W. Gabriel. 2004. Improved sampling methods for real-time polymerase chain reaction diagnosis of citrus canker from field samples. Phytopathology 94, 61-68. Doi: 10.1094/ phyto.2004.94.1.61
Mazorra, M.F., Á.P. Quintana, D. Miranda, G. Fischer, and M. Chaparro de Valencia. 2006. Aspectos anatómicos de la formación y crecimiento del fruto de uchuva Physalis peruviana (Solanaceae). Acta Biol. Colomb. 11(1), 69-81.

McDaniel, G.L., G.J. Buck, and R.E. Ford. 1971. Isolation of tobacco ringspot virus from rose. Phytopathology $61,45-49$

Mollov, D., B. Lockhart, and D. Zlesak. 2012. Identification, transmission, and genomic characterization of a novel member of the Caulimoviridae causing a yellow vein disease of cultivated rose. pp. 82-82. In: Phytopathology. American Phytopathological Society, St. Paul, MN, USA.

Morales, F.J., I. Lozano, M. Castaño, J. Arroyave, A.C. Velasco, and F. Varón. 2002. Partial characterization of a Tymovirus infecting passion fruit in Colombia, South America. J. Phytopathology 150(4-5), 292-296. Doi: 10.1046/j.1439-0434.2002.00740.x

PMA (Produce Marketing Association). 2015. Colombian Floral Industry Overview. In: www.pma.com/ content/articles/2015/04/colombian-floral-industry-overview; consulted: January 2018.

Rodríguez, M.H., N. Niño, J. Cutler, J. Langer, F. Casierra-Posada, D. Miranda, and C. Büttner. 2016. Certification of healthy plant material in Colombia: A critical analysis of opportunities and challenges to control virus diseases. Rev. Colomb. Cienc. Hortíc. 10(1), 164-175. Doi: 10.17584/rcch.2016v10i1.4921

Sertkaya, G. 2010. An investigation on rose mosaic disease of rose in Hatay Turkey. In: Proc. $21^{\text {st }}$ International Conference on Virus and other Graft Transmissible Disease of Fruit Crops, 5-10 July 2009. Neustadt, Germany. Julius-Kühn-Archiv 427, 309-313.

Vaca-Vaca, J.C., E.C. Carrasco-Lozano, and K. López-López. 2017. Molecular identification of a new begomovirus infecting yellow passion fruit (Passiflora edulis) in Colombia. Arch. Virol. 162, 573-576. Doi: 10.1007/ s00705-016-3098-y

Von Bargen, S., R. Demiral, and C. Büttner. 2015. First detection of Raspberry ringspot virus in mosaic diseased hybrid roses in Germany. New Dis. Rep. 32, 18. Doi: 10.5197/j.2044-0588.2015.032.018 